特 集

最新放射線化学（応用編）

\title{
14 放射線化学を利用した線量計測と国際規格
}

\author{
小嶋拓治 ${ }^{\dagger, \# ~}$ \\ 国立研究開発法人量子科学技術研究開発機構 \\ 370-1292 群馬県高崎市綿貫町 1233 \\ ${ }^{\dagger}$ kojima.t@beamope.co.jp
}

\begin{abstract}
放射線加工や医療分野などにおける吸収線量の測定には，いわゆる化学線量計が用いられてお り，その原理や製造などに放射線化学が活かされている。放射線利用における品質管理・品質保 証などの手段としての有用性，それらの標準化の基盤となる国際規格との関わりなどとともに紹 介する。
\end{abstract}

Key Words: dosimetry, radiation chemistry, radiation applications, quality assurance, standards

\section{1. 放射線化学を利用した線量計測}

血液検査や献血時に，包装済みの採血用注 射筒が入った箱を見て「電子線滅菌済み」の表 示があることに気づかれた方もおられるのでは ないだろうか。このような表示が必ずしもな されてはいないが, 主としてコバルト 60 線源 の $\gamma$ 線や加速器・発生装置で生成した電子（電 子線）を利用して, 医療機器・ヘルスケア用品 や食品包装材・容器などの滅菌, 家電製品・自 動車用電線の耐熱性被覆材・配線集束用熱収縮 チューブや吸着・捕集・選択透過性などを持つ 機能性ポリマーへの改質などが, 私たちの生活 の中で広く行われている。

こうした処理・製造のためには，どれだけの 量の放射線をどのように照射するか，また，こ の処理に伴って生じる材質等の変化などが私た ちの健康や安全に及ぼす影響や目的とする製品 の品質低下を無視しうる程度にするにはどの ように行えば良いのか，などを考える上で，そ の尺度となるのが, 吸収線量 (以下線量) であ

\footnotetext{
\#客員研究員
}

る。

この線量を測定する線量計には，国際的に 水を標準物質としているので組成がそれに近い こと，一連の照射にわたる積分線量が測定でき ること，照射場及び照射対象物内の分布も測定 できるように小型であること，信号ケーブルを 使用せず照射対象物との容易に等価の置き換え が容易で簡便な取り扱いができることなどが求 められる。

放射線の利用では, 放射線化学反応に基づ いているものも多く，同様に放射線化学反応に 基づき線量計としての要件をほぼ満たすことが できるいわゆる化学線量計が一般的に用いられ ている。以下，順不同で例を挙げる。

医療機器・ヘルスケア製品の滅菌では, 吸 収線量に比例してポリメチルメタクリレート （PMMA）中に生成する不飽和結合に起因する 着色を吸光度として分光光度計により定量する 方法に基づく PMMA 線量計が主として用いら れている。この定量において, PMMAに生成 したラジカルが照射後の酸素の拡散により別の 紫外光吸収スペクトルを持つラジカルに変化 して影響を与えることなどの反応機構にかか 
わる研究もなされている ${ }^{1)}$ 。透明PMMA 線量 計RadixW ${ }^{2)}$ は, 日本原子力研究所（現量子科 学技術研究開発機構）が(株)ラジエ工業と共同 開発しさらに測定範囲と安定性を改良したもの で，異なる色素含有PMMA 線量計を複数使用 して測定する数 $-100 \mathrm{kGy}$ の線量範囲に利用され ている。また，電子線の線量計測には，三酷酸 セルロース（CTA）, ナイロン，ポリビニルブ チラル, 塩化ビニル, ポリエチルテレフタレー ト（PET）などの透明なフィルムに, トリフェ ニルフォスフェート, トリフェニルメタンのロ イコシアニドやロイコメトキシド，パラロスア ニリン，あるいはアゾ色素などをそれぞれ含有 させたフィルム状の線量計が用いられている。 このCTA線量計 RN-125 は, 日本原子力研究所 (現量子科学技術研究開発機構) が日仏協力の 下で富士フィルム (株) と研究・開発したもの である ${ }^{3)}$ 。これらのフィルム状線量計について は, 基材のポリマー及び添加された可塑剂や色 素の分解反応や分解生成物間の反応機構, 照射 後の経時変化における酸素の拡散の影響などの 評価に放射線化学研究が活かされている4)。

わが国での食品の放射線加工処理には，1972 年以来北海道で行われているばれいしょの芽止 めを目的とした $\gamma$ 線照射があるが，その工程管 理には, 放射線の吸収線量に比例して水溶液中 に水の分解により生成する $\mathrm{OH}$ ラジカルによる 酸化反応の結果, 硫酸第一鉄イオン $\mathrm{Fe}^{2+}$ が $\mathrm{Fe}^{3+}$ になり, $\mathrm{Fe}^{3+}$ 濃度に比例する吸光度を分光光度 計により定量する方法に基づく硫酸第一鉄（フ リッケ）線量計が用いられている。水溶液中の 有機不純物が酸化反応を阻害することやそれを 塩化ナトリウム共存の系で回避する機構など について1960年代から研究が行われた ${ }^{5,6)}$ 。フ

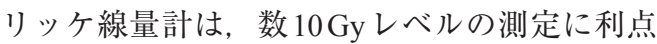
があり,このほかウリミバエ/ゾウムシの不妊 化処理施設などでも利用されている7)。

陽子線や炭素線を用いた粒子線治療におけ る強度変調放射線治療などの治療計画を正確に 評価・検証するために高い位置精度や線量精
度が要求される 3 次元可視化では，アクリルア ミドやメタクリル酸，イソプロピルアクリルア ミドなどの種々のビニルモノマーのラジカル 重合・析出を MRIやX線／光学的 CT装置で3 次元的に読み出すポリマーゲル線量計の開発・ 試用が行われている ${ }^{8)}$ 。また，植物由来のセル ロース系の電子線架橋によるゲル線量計母材の 開発も行われている ${ }^{9)}$ 。なお，治療を計画する 上での予備照射には，透明なPETフィルムを 表裏サンドウィッチしたジアチレン含有層の放 射線着色に基づく $\mathrm{GAF}$ 線量計が， $20 \mathrm{~cm}$ 角程度 の広さにわたる $0.1 \mathrm{~Gy}-1 \mathrm{kGy}$ の範囲の線量分布 のイメージング手段として利用されている ${ }^{10)}$ 。

宇宙線計測や生物照射実験におけるイオン ビーム計測には, CR-39 $\left(\mathrm{C}_{12} \mathrm{H}_{18} \mathrm{O}_{7}\right)$ というポ リマーが放射線照射により，その飛跡に沿って 化学結合が切れて化学薬品に溶解しやすくなる ことを利用した固体飛跡検出器が用いられてい る。線量が直接読み取れるものではないが, 線 量評価の基となる粒子のエネルギーと個数が同 時に計測できる。従来は軽イオンに対する感度 は低かったが，N-イソプロピルアクリルアミド との共重合体の開発による高感度化がなされ， 反跳陽子を利用した中性子の測定への応用まで も可能な検出器が市販されている ${ }^{11)}$

チェルノブイリ原子炉事故での放射線量を 評価する目的で，家庭や近傍のレストランの砂 糖が用いられたことがある。放射線分解で生 じた砂糖の C-H結合が切断されて生じるラジ カル濃度を, 電子スピン共鳴（ESR）装置で定

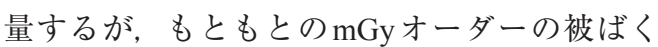
で生じるラジカル数は少ないことや砂糖によっ て不純物濃度が異なるので，人為的に既知の線 量を照射し，その信号強度と線量の関係を原点 に外挿する付加線量方式を用いて評価が行われ た ${ }^{12)}$ 。

放射線照射機器・施設や放射性廃棄物から の漏えいなどによる 0.1 -数 $10 \mathrm{~Gy}$ の微量放射線 を可視化・管理する目的で, 有機溶媒やポリ マー（酸発生剤を添加する場合もある）に生じ 
る酸などにより発色するフルオラン系やベンゾ ジキサンテン系などラクトン環内包の機能性 色素, ジアチレンの固相重合反応, フォトクロ ミック色素であるジアリールエテンを用いたカ ラー線量計の研究開発も行われており, 実用化 に向けて種々の系による高感度化や照射後の安 定化に関する研究などが進んでいる ${ }^{13-15) 。 ~}$

いわゆる線量計測とは若干異なるが, 日本 で許可しているばれいしょ以外で放射線照射さ れた畜産・農林水産物が食品に混入していない かを検知する方法に, 野菜・果実やあさり・エ ビなどに生成したケイ酸塩の欠陥を測定する物 理化学的手法として熱ルミネセンス（TL）法 がある。このほかに, (1)食品中の脂肪分中に 放射線の電離作用で生成したドデシルシクロブ タノン（DCB）及びテトラデシルシクロブタ ノン（TCB）を GC-MS（ガスクロマトグラフ . 質量分析計）で測定する方法, 及び(2)乾燥果物 などに含まれる結晶性糖類に生成したラジカル を電子スピン共鳴（ESR）装置を用いて測定す る放射線化学に基づく2つの方法が公定法とし て用いられており, 水際での違反食品の検出に 役立っている16)。

\section{2. 線量計の役割}

放射線を利用した処理・製造では，滅菌な どの所期の目的の達成, 及びこの処理に伴って 生じる材質変化等の抑制にかかわる再現性の確 認が重要である。この手段となる化学線量計に よる線量計測は，次の役割を果たしている。

(1)実験室規模で，好ましい照射効果と線量との 相関を得る。また, その効果について, 温度 や時間などの照射条件の影響を調べ, 再現性 を把握する。

(2)加工工程を構成する放射線源及び照射対象物 の搬送装置など仕様が設計通りであることの 確認。据付時適格性確認 (IQ)。

(3)運転時における照射場の特性や照射製品内の 線量分布などが設計通りであることを確認す る。運転時適格性確認 (OQ)。
(4)上記項目と重複するものも多いが，照射対象 物について, 照射場の特性や照射製品内の線 量分布, 製品の品質の範囲にかかわる最大最 小線量值及びそれらを与える箇所，それらを 日常的にモニターするときにそれが難しい場 合に相関を明らかにして決定した線量計測参 照点の位置などの再現性を確認する。稼働性 能適格性確認 $(\mathrm{PQ})$ 。

(5)最大・最小線量值あるいは, 線量計測参照点 における日常的にモニターすることにより， 全処理工程が許容範囲内で再現性良く実施さ れていることの確認。

特に, 滅菌のように, 照射後健康に影響を 与えるような残留菌や化学成分の溶出等が製品 にないことの保証が不可欠な放射線処理では, この手段となる, 読み取りに用いる装置類を含 めた線量計測システムについて，その信頼性を 確保するため, 最適な線量計測システムの選 択, 的確な取り扱い方法, 線量計測值の読み取 り方法などを規定した国際規格などが整備され ている。さらには, 線量值について, 国家標準 あるいは国際標準にトレーサブル（遡及可能） であり，影響因子の効果を含めた不確かさが導 出できることが要求される ${ }^{17)}$ 。

この標準への遡及性を確保する手段には, 主としてアラニン線量計が用いられている。ア ラニン線量計は, アラニン粉末結晶中に放射 線照射で生じたラジカルの量を ESR 装置で読 み取ることで, $1 \mathrm{~Gy}-100 \mathrm{kGy}$ の範囲が測定でき る。また，室温で長期に安定な信号を保持して いることから, 校正認定機関からアラニン線量 計を放射線処理施設に送り，そこで使用してい る線量計と同時に照射後返送されたアラニン線 量計を線量校正認定機関で読み取り, この結果 に基づき処理施設で用いる線量計の線量応答曲 線（あるいは算出式）を作成するというトラン スファー線量計測という校正方法に用いられ ている ${ }^{4)}$ 。アラニン線量計は, 放射線加工処理 における自国及び国際的な基準線量計として 英米仏中などの線量標準機関で活用されてい 
る。また, 日本原子力研究所（現量子科学技術 研究開発機構) が1986年に日立電線(株) (現日 立金属(株)と共同開発した線量計素子を用いた 国際原子力機関（IAEA）の国際線量保証サー ビス（IDAS）が1992年から 2005 年まで実施さ れ, 加盟国の大線量域の標準化の進展に貢献し た ${ }^{18)}$ 。

\section{3. 国際規格等との関わり}

放射線滅菌等の処理に使用される放射線化 学を利用した線量計について, これらの線量 計特性を関連規格とともに表 1 に一覧として示 す ${ }^{19-29)}$ 。線量計は上から下に順に液体, 固体, 及び結晶の固化体である。

放射線加工処理の中でも，ヘルスケア用品の 放射線滅菌のように, 滅菌状態や照射後の製品 から健康に影響を与えるような残留菌数や化学 成分の溶出量等がないことなどの保証が要求 されるものについては, 放射線処理全体につ いてICRU Report 80 30) 及 びISO11137-3（JIS T 0806-3) 31) などが定められている。また，表1
の化学線量計の使用にあたっては，目的にあっ た特性をもつ線量計を選択する必要があり，そ の指針となる ISO/ASTM 52628 ${ }^{32)}\left(\right.$ JIS Z 4574) ${ }^{33)}$ 及び5270134) が制定されている。

以下，個別の規格について，若干補足する。

フリッケ線量計については, 日本では, 厚 生労働省医薬・生活衛生局発出の「フリッケ線 量計によるばれいしょの放射線照射線量の測定 法について（食安発0916第2号，H23.09.16）」 及び同通知の一部改正（生食発 0331 第 9 号, H28.03.31）がこの国際規格に準拠したものと して有効である。硫酸第二セリウム及び重クロ ム酸線量計は，溶液をアンプル化したものがカ ナダとイギリスでトランスファー線量計として 用いられており，日本でも一部ではそれらを利 用している。エタノールクロロベンゼンは，日 本での使用はなく，ハンガリーやフィリピンで 用いられている。この他の表中の固体状線量計 は，取扱いが容易で，いずれの線量計も市販品 があり，国際的に広く用いられている。

なお, 重クロム酸線量計, PMMA線量計

表1 放射線化学反応を利用した線量計測システム例

\begin{tabular}{|c|c|c|c|}
\hline 種 類 & 原 & $\begin{array}{l}\text { 線量範囲 } \\
\text { (Gy) }\end{array}$ & 関連規格 \\
\hline 硫酸第一鉄（フリッヶ） & $\begin{array}{l}\text { 硫酸水溶液中 } \mathrm{Fe}^{2+} \rightarrow \mathrm{Fe}^{3+} \text {, } \\
\text { 吸光度 }\end{array}$ & $20-4 \times 10^{2}$ & ISO/ASTM5 $1026^{19)}$ \\
\hline 硫酸セリウム & $\begin{array}{l}\text { 硫酸水溶液中 } \mathrm{Ce}^{4+} \rightarrow \mathrm{Ce}^{3+} \text {, } \\
\text { 吸光度 }\end{array}$ & $5 \times 10^{2}-10^{5}$ & ISO/ASTM5 $1205^{20)}$ \\
\hline 重クロム酸 & $\begin{array}{l}\mathrm{Ag} \text { 存在下 } \mathrm{Cr}_{2} \mathrm{O}_{7}{ }^{2-} \rightarrow \mathrm{CrO}_{4}{ }^{2-} \text {, } \\
\text { 吸光度 }\end{array}$ & $2 \times 10^{3}-5 \times 10^{4}$ & ISO/ASTM5140121) \\
\hline $\begin{array}{l}\text { エタノールクロロベン } \\
\text { ゼン }\end{array}$ & $\begin{array}{l}\mathrm{HC} \text { |イオン生成, } \\
\text { 伝導率 }\end{array}$ & $10 \quad-2 \times 10^{6}$ & ISO/ASTM5 $1538^{22)}$ \\
\hline PMMA*(透明、着色) & $\begin{array}{l}\text { 分解による着色/着色増加, } \\
\text { 吸光度 }\end{array}$ & $10^{3}-10^{5}$ & $\begin{array}{l}\text { ISO/ASTM5 } 1276^{23)} \\
\mathrm{JISZ} 4572^{24)}\end{array}$ \\
\hline 三酢酸セルロース(CTA) & $\begin{array}{l}\text { 可塑剤共存下の CTA の着色, } \\
\text { 吸光度 }\end{array}$ & $5 \times 10^{3}-2 \times 10^{6}$ & $\begin{array}{l}\text { ISO/ASTM5 } 1650^{25)} \\
\mathrm{JISZ} 4573^{26)}\end{array}$ \\
\hline $\begin{array}{l}\text { ラジオクロミックフィ } \\
\text { ルム }(\mathrm{FWT}-60, \mathrm{~B} 3)\end{array}$ & $\begin{array}{l}\text { ナイロン中の色素の着色, } \\
\text { 吸光度 }\end{array}$ & $10^{3}-10^{5}$ & ISO/ASTM5 $1275^{27)}$ \\
\hline 同 (GAF) & $\begin{array}{l}\text { ポリェチルテレフタレート内 } \\
\text { の色素の着色, } \\
\text { 吸光度 }\end{array}$ & $10^{-1}-10^{3}$ & (ISO/ASTM51275) \\
\hline アラニン & $\begin{array}{l}\text { ラジカル生成, } \\
\mathrm{ESR}^{* *} \text { *信号強度 }\end{array}$ & $1-10^{5}$ & $\begin{array}{l}\text { ISO/ASTM5160728) } \\
\text { JISZ4571 } 29)\end{array}$ \\
\hline
\end{tabular}

*PMMA：ポリメチルメタクリレート，**ESR(EPR):電子スピン共鳴 
(透明及び着色), CTA 線量計，及びアラニン線 量計にかかわるISO/ASTM規格には，日本の基 礎的研究成果も寄与している ${ }^{35-37) 。 ~}$

\section{おわりに}

放射線滅菌という製品加工や放射線治療な ど，私たちの生活の中の放射線利用関連分野に おいて，それが安全かつ安定に実施されている ことを保証する手段の一つとして，放射線化学 を利用した線量計が役立っている。普遍的な結 果を生む学術的なものとは異なるが，1950年 代に開始された液体や固体の放射線化学研究の 積み重ねが,「国際規格」という世界共通の実 用的計測技術の基盤構築に結び付いた例と考え る。

\section{文献}

1) Barrett, J. H., Dosimetry with dyed and undyed acrylic plastic, Int. J. Appl. Radiat. Isot., 33, $1177-$ 1187 (1982)

2) Seito, H., Ichikawa, T., Haneda, N., Kaneko, H., Sato, Y., Watanabe, H. and Kojima, T., Characteristics study of clear polymethylmethacrylate dosimeter, Radix W, in several kGy range, Radiat. Phys. Chem., 78, 356-359 (2009)

3) Tamura, N., Tanaka, R., Mitomo, S., Matsuda, K. and Nagai, S., Properties of cellulose triacetate dose meter, Radiat. Phys. Chem. (1977), 18, 947-956 (1981)

4) McLaughlin, W. L., et al., Dosimetry for radiation processing, Chapter 8, Taylor \& Frances, London (1989)

5) Fricke, H. and Hart, E. J., Radiatin Chemistry, eds. Attix F. H. and Roesch, W. C., Vol. II, Academic Press, New York (1966)

6) Matthews, R. W., Aqueous chemical dosimetry, Int. J. Appl. Radiat. Isot., 33, 1159-1170 (1982)

7) http://www.pref.okinawa.jp/mibae/index.html

8) 林 慎一郎, ポリマーゲル線量計, 放射線化 学, 93, 23-30 (2012)

9) Hiroki, A., Yamashuta, S., Kimura, A., Nagasawa, N. and Taguchi, M., Effect of heavy ion irradiation on optical property of radiation-crosslinked hydroxypropyl cellulose gel containing methacrylate monomers, Nucl. Instrum. Meth. in Phys Res. Sec. B, 365,
583-586 (2015)

10) 成山展照, 光の強度を測る $\mathrm{I}$ 一電離箱とフィル 厶—，放射光， 21，99-105（2008）

11）金崎真聡, 福田祐仁, 榊 泰直, 西内満美子, 近藤公伯，倉島 俊，神谷富裕，服部篤人，小 田啓二, 山内知也，イオンビーム特性評価を 目的とした固体飛跡検出器CR-39の利用, $J$ Plasma Fusion Res., 88, 261-275（2012）

12) Ikeya, M., New Applications of Electron Spin Resonance-Dating, Dosimetry and Microscopy, World Scientific $(1993 ; 2002)$

13）中澄博行, 高感度な放射線感応物質の開発とそ の応用, Isotope News, No. 535, 2-3（1998）

14）時田澄男, 高感度 $\gamma$ 線検出のための機能性色素, 放射線化学，76, 29-33（2003）

15）入江せつ子，入江正浩, ジアリールエテンを 用いた高感度カラー線量計，放射線化学， 85 , 20-24 (2008)

16) http://www.mhlw.go.jp/topics/yunyu/other/2012/ dl/120910-02.pdf

17) ISO/ASTM51707 Standard Guide for Estimation of Measurement Uncertainty in Dosimetry for Radiation Processing

18) http://www.bipm.org/cc/CCRI(I)/Allowed/18/ CCRI(I)07-32.pdf

19) ISO/ASTM51026 Standard Practice for Using the Fricke Dosimetry System

20) ISO/ASTM51205 Standard Practice for Use of a Ceric-Cerous Sulfate Dosimetry System

21) ISO/ASTM51401 Standard Practice for Use of a Dichromate Dosimetry System

22) ISO/ASTM51538 Standard Practice for Use of the Ethanol-Chlorobenzene Dosimetry System

23) ISO/ASTM51276 Standard Practice for Use of a Polymethylmethacrylate Dosimetry System

24) JIS Z4572:2013ポリメチルメタクリレート線量 計測システムの標準的使用方法

25) ISO/ASTM51650 Standard Practice for Use of a Cellulose Triacetate Dosimetry System

26) JIS Z4573:2015三酢酸セルロース線量計測シス テムの使用方法

27) ISO/ASTM51275 Standard Practice for Use of a Radiochromic Film Dosimetry System

28) ISO/ASTM51607 Standard Practice for Use of the Alanine-EPR Dosimetry System

29) JIS Z 4571:2001アラニン線量計測装置

30) ICRU Report 80: Dosimetry Systems for Use in Radiation Processing

31) http://kikakurui.com/t0/T0806-3-2010-01.htm 
32) ISO/ASTM52628 Standard Practice for Dosimetry in Radiation Processing

33) JIS Z 4574: 2017 放射線加工処理における線量計 測方法

34) ISO/ASTM52701 Standard Guide for Performance Characterization of Dosimeters and Dosimetry Systems for Use in Radiation Processing

35) 例えば Mai, H. H., Tachibana, H. and Kojima, T., Effects of temperature during irradiation and spectrophotometry analysis on the dose response of aqueous dichromate dosimeters, Radiat. Phys. Chem., 53, 85-91 (1998)

36) 例えば Kojima, T. and Tanaka, R., Polymer-alanine dosimeter and compact reader, Appl. Radiat. Isot., 40, 851-857 (1989)

37) 例えば Kudoh, H., Celina, M., Kaye, R. J., Gillen, K. T. and Clough, R. L., Response of alanine dosimeters at very high dose rate, Appl. Radiat. Isot., 48,
497-499 (1997)

\begin{abstract}
Modern Radiation Chemistry (Applications)

14 Dosimetry on the Basis of Radiation Chemistry and Related International Standards

Takuji KoJima $^{\dagger}$ : Guest researcher, National Institutes for Quantum and Radiological Science and Technology, 1233 Watanukimachi, Takasaki-shi, Gunma Pref. 370-1292, Japan†kojima.t@beamope.co.jp

Dosimetry systems whose principle or design are base on radiation chemistry, so-called chemical dosimetry systems, are applied to absorbed dose measurements in radiation processing and radiomedical diagonostic treatment. Such dosimetry systems are overviewed assosiating with their useful roll for quality control/quality assurance, related international standards for their standardization, and so on.
\end{abstract}

